\title{
Analisis Kebijakan Formulasi Sistem Pertanggungjawaban Korporasi dan Aplikasinya Dalam Perlindungan Kesehatan dan Keselamatan Kerja (K3)
}

\author{
Parningotan Malau ${ }^{1) *}$ \\ 1)Program Studi Ilmu Hukum, Fakultas Ilmu Sosial dan Humaniora, Universitas Putera Batam, \\ Indonesia
}

Diterima Februari, 2020; Disetujui April, 2020; Dipublikasikan Juni ,2020

\begin{abstract}
Abstrak
Tujuan penulisan ini adalah untuk mengetahui kebijakan formulasi Sistem Korporasi dalam perlindungan kesehatan dan keselematan kerja (K3) mengggunakan grand theory Moh. Kusnardi dan Harmaily Ibrahim. Perlindungan K3 pekerja/buruh harus diwujudkan atas unsur-unsur komunal, religius dan kekeluargaan. Regulasi keselamatan kerja harus berperan menjaga fungsi sistem sosial bagi pekerja/buruh dalam kedudukannya yang lemah atas korporasi/pengusaha yang mendapatkam keuntungan dan kenikmatan dari kegiatan usahanya. Desain pada penelitian ini menggunakan penelitian kualitatif dan didukung oleh data sekunder yaitu dokumen undangundang kesehatan dan keselamatan kerja sebagai wujud regulasi dalam melindungi pkerja/buruh. Tehnik pengumplan data dilakukan dengan wawancara dan dokumentasi. Sedangkan tehnik analisis data dilakukan dengan analisis kualitatif yaitu reduksi data, verifikasi data dan memberikan kesimpulan. Dari hasil penelitian disimpulkan bahwa Kebijakan formulasi sistem pertanggungjawaban kejahatan korporasi yang ideal dalam perlindungan K3 adalah dengan merujuk kepada Pancasila. Negara hukum Pancasila harus menjunjung tinggi sistem hukum yang menjamin kepastian hukum untuk melindungi pekerja/buruh dari setiap perilaku kejahatan korporasi. Upaya tersebut dilakukan dengan merumuskan secara eksplisit hukum korporasi yang dapat dibebani pertanggungjawaban, merumuskan kualifikasi perbuatan (regulatory offences) yang dapat dianggap sebagai tindak kejahatan korporasi, sesuai dengan Undang-Undang (UU) K3 dengan memperhatikan perkembangan sanksi terhadap korporasi.
\end{abstract}

Kata Kunci: Kebijakan, Formulasi, Korporasi, Kesehatan, Keselamatan

\section{Abstract}

Worker Occupational Safety and Health (OSH) protection must be realized on communal, religious and family elements. Work safety regulations must play a role in safeguarding the functioning of the social system for workers / laborers in their weak position over corporations / entrepreneurs who benefit from the enjoyment of their business activities. The design in this study uses qualitative research and is supported by secondary data, namely occupational health and safety law documents as a form of regulation in protecting workers / laborers. Data collection techniques are carried out with interviews and documentation. While the technique of data analysis is done by qualitative analysis namely data reduction, data verification and giving conclusions. From the results of the study concluded that the policy formulation of an ideal corporate crime responsibility system in OSH protection is referring to Pancasila. The Pancasila state law must uphold a legal system that guarantees legal certainty to protect workers / laborers from any corporate criminal behavior. These efforts are made by explicitly formulating corporate law that can be burdened with responsibility, formulating qualifications for acts (regulatory offences) that can be considered as corporate crime, in accordance with laws OSH by taking into account the development of sanctions against corporations.

Keywords: Policies, Formulations, Corporations, Health, Safety

How to Cite: Malau, P. (2020). Analisis Kebijakan Formulasi Sistem Pertanggungjawaban Korporasi dan Aplikasinya Dalam Perlindungan Kesehatan dan Keselamatan Kerja (K3). PUBLIKAUMA: Jurnal Ilmu Administrasi Publik UMA, 8 (1): 11-17

*Corresponding author: ISSN 2549-9165 (Print)

E-mail: pmalau0707@gmail.com ISSN 2580-2011 (Online 


\section{PENDAHULUAN}

Perusahaan berpotensi melakukan pelanggaran terhadap keselamatan dan kesehatan kerja dalam kapasitasnya sebagai pemberi kerja (dan mungkin juga sebagai pengusaha). Perusahaan melakukan kinerja tugas yang dapat menyebabkan cedera atau kematian bagi pekerja mereka dan membahayakan publik (Hassan, 2014).

Tanggung jawab perusahaan untuk bencana semacam itu bisa sangat parah, dan perusahaan mungkin diharuskan membayar sejumlah besar uang sebagai hukuman berdasarkan Undang-Undang. Selain itu, kecelakaan industri yang disebabkan oleh kelalaian korporasi dapat merusak reputasi perusahaan tersebut.

Betapapun mulianya tujuan UndangUndang, tidak akan efektif jika penegakan hukum lemah. Agar setiap Undang-Undang dihormati, harus memiliki dampak positif pada industri dan masyarakat. Jumlah kecelakaan industri dan penyakit akibat kerja meningkat pada tingkat yang mengkhawatirkan dan K3 memiliki peran penting dalam bertindak sebagai katalis untuk menciptakan kesadaran keselamatan di kalangan pengusaha dan karyawan (Hassan, 2014). Julmlah kasus kecelakaan kerja tersebut dapat dilihat pada tabel 1. berikut ini:

Tabel. 1 Data Jumlah Kecelakaan

\begin{tabular}{|c|c|c|c|}
\hline No. & Tahun & $\begin{array}{c}\text { Jumlah } \\
\text { Kasus }\end{array}$ & Fatalitas \\
\hline 1. & 2015 & 110.285 & 2.308 \\
\hline 2. & 2016 & 101.367 & 2.382 \\
\hline 3. & 2017 & 123.000 & 3.000 \\
\hline 4. & 2018 & 173.105 & 2.575 \\
\hline 5. & 2019 & 85.100 & \\
\hline
\end{tabular}

Sumber: Kementerian ketenagakerjaan tahun 2019

Berdasarkan data kecelakaan di atas, Kementerian Tenaga Kerja, yang diakui sebagai standar (K3) di Indonesia, masih buruk, setiap hari 8 (delapan) pekerja meninggal dunia. ILO memberikan informasi tentang kondisi tempat kerja. Kekhawatiran yang sama juga disampaikan oleh Lembaga Perburuhan Indonesia, Inisiatif Lokal untuk Jaringan K3 (LION), dan Aliansi Rakyat untuk K3. Kementerian Tenaga Kerja mengingatkan industri untuk meningkatkan tuntutan normanorma K3 dan menuntut komitmen untuk memberikan kepastian hukum dan menegakkan undang-undang tentang implementasi K3. Terkait dengan protes tersebut, terbukti bahwa maraknya kejahatan pekerja / perlindungan buruh K3 tidak diikuti oleh penegakan hukum (Running Text Metro TV, 2014). Selama 25 tahun setelah kemerdekaan, Indonesia masih memberlakukan peraturan keamanan (Veiligheids reglement) Stbl. 1910 No. $406 \mathrm{di}$ pabrik dan tempat kerja hingga keluarnya UUKK pada 12 Januari 1970.

Tanggung jawab internal untuk kesehatan dan keselamatan kerja masih menjadi masalah saat ini. Ini memerlukan banyak tantangan dan masalah, terlepas dari tujuan Undang-Undang Kesehatan dan Keselamatan Kerja. Untuk menjamin pencapaian tujuan yang ambisius ini, Undangundang Kesehatan dan Keselamatan Kerja harus menetapkan tujuan untuk menghilangkan sumber bahayanya terhadap kesehatan, keselamatan dan integritas fisik pekerja.

Hal tersebut berhubungan dengan mekanisme partisipasi untuk memastikan organisasi memikul tanggung jawab internal untuk kesehatan dan keselamatan kerja. Oleh karena itu dibutuhkan suatu formulasi kebijakan pembentukan organisasi seperti komite kesehatan dan keselamatan, program pencegahan, dan perwakilan khusus untuk pencegahan, dan program kesehatan di setiap pendirian perusahaan.

Selain itu, ada banyak masalah yang terkait dengan kesehatan dan keselamatan kerja. Antara lain mencari penghematan biaya dan penghematan waktu, serta nilai tambah yang terkait dengan motivasi dan kepuasan pekerja.

Nilai tambah lainnya terkait dengan inovasi dalam produk dan citra perusahaan yang lebih baik. Di Prancis, misalnya, pengurangan berkelanjutan sekitar 20\% per tahun dalam kecelakaan di tempat kerja telah memungkinkan perusahaan untuk menjadi lebih kompetitif sambil membuktikan bahwa mereka menghormati norma kesehatan dan keselamatan kerja. (Mouton, 2006).

Penelitian (Munar, 2010) memberikan beberapa contoh terkait dengan kesehatan dan keselamatan kerja untuk 35 perusahaan di Polandia $70 \%$ perusahaan telah secara signifikan mengurangi tingkat kecelakaan 
mereka, 50\% telah mengurangi jumlah pekerja dalam kondisi berbahaya, dan $70 \%$ menikmati premi asuransi yang lebih rendah. Ini membuktikan bahwa bermanfaat bagi perusahaan-perusahaan dalam hal peningkatan kepuasan pelanggan dan kesehatan dan keselamatan kerja.

Disisi lain mencegah kecelakaan industri dapat dilihat dari perspektif tanggung jawab pidana. Sebagian besar telah ditulis tentang pertanggungjawaban perusahaan atas kecelakaan industri khususnya dalam konteks hukum gugatan. Sehingga diperlukan suatu rumusan kebijakan system pertanggungjawaban korporasi dalam menerapkan perlindungan terhadap pekerja atau buruh.

Pendekatan peraturan menekankan penerapan peraturan untuk mencegah risiko pekerjaan. Ini mengedepankan langkahlangkah dan peraturan hukum yang diadopsi oleh negara untuk mencegah risiko dan bahaya di tempat kerja. Meskipun langkah-langkah pencegahan untuk cedera kerja mulai secara resmi ditetapkan di setiap Negara.

Pendekatan pengaturan juga bergantung pada mekanisme pencegahan. Selain itu, sistem pencegahan-inspeksi harus dapat memastikan penerapan Undang-Undang dalam organisasi. (Fidèle Ndjoulou, 2015). Dengan demikian, tujuan dari penulisan ini untuk membahas rumusan kebijakan dan tanggung jawab perusahaan dalam melindungi pekerja atau buruh.

Penelitian ini sangat penting, sehingga dapat diketahui akar penyebab kegagalan fungsi dan tidak dapat dikonfirmasi UUK3 dalam upaya penanggulangan perlindungan pidana terhadap karyawan / pekerja K3. Fungsi UUKK dapat diartikan sebagai kegagalan kebijakan kriminal sebagai bagian dari kebijakan penegakan hukum, yang secara keseluruhan merupakan bagian dari politik sosial (social policy), yaitu upaya masyarakat atau negara untuk meningkatkan kesejahteraan rakyat (Muladi, 1990).

Seperti juga dinyatakan Barda Nawawi Arief, kebijakan kriminal ini tidak lepas dari kebijakan yang lebih luas, yaitu kebijakan sosial melalui perumusan kebijakan atau upaya kesejahteraan sosial dan kebijakan pertahanan sosial (Barda Nawawi Arief, 1990).

\section{METODE PENELITIAN}

Metodologi penelitian yang diadopsi dalam penulisan ini adalah melalui penerapan pendekatan kualitatif. Pentingnya adalah untuk menunjukkan bahwa penelitian ini bertumpu pada penelitian teoritis, akademis atau konvensional. Penelitian ini membahas dan mengadaptasi perlindungan hukum di bawah hukum keselamatan dan kesehatan kerja disamping analisis peraturan UndangUndang (Yaqin, 2007).

Analisis yang diterapkan dengan pendekatan analitis dan kritis di seluruh penelitian. Sebagai pendukung dalam penelitian ini lebih lanjut didasarkan studi berbasis perpustakaan, yang berarti bahwa bahan yang diperlukan untuk penelitian harus tersedia di perpustakaan, arsip, dan database. Tujuan dasar dari penelitian ini adalah untuk menemukan, menjelaskan, memeriksa, menganalisis dan menyajikan fakta, prinsip, ketentuan, konsep, teori atau cara kerja hukum tertentu dalam bentuk sistematis; dengan demikian, ini adalah penelitian kualitatif.

Penelitian ini juga bergantung pada data yang dikumpulkan dari publikasi pemerintah. Untuk memahami pola dan masalah yang terlibat dalam penghukuman liabilitas pidana oleh pelanggar di bawah keselamatan dan kesehatan kerja. Peneliti mengadaptasi data yang muncul dalam jurnal pendakwaan.

\section{HASIL DAN PEMBAHASAN \\ Sistem Hukum Pancasila Sebagai Pertanggungjawaban Korporasi}

Dalam konteks perlindungan K3 pekerja/buruh, negara hukum Pancasila harus menjunjung tinggi sistem hukum yang menjamin kepastian hukum untuk melindungi pekerja/buruh dari setiap perilaku kejahatan korporasi (corporate crime) yang dapat mengganggu terciptanya kesejahteraan itu. Karena, mustahil kesejahteraan pekerja/buruh dapat diwujudkan sebagaimana cita-cita bangsa Indonesia, jika di tempat kerja sering terjadi tindak pidana perlindungan K3 pekerja/buruh.

Pengabaian atau tidak melaksanakan perlindungan K3 pekerja/ buruh adalah bagiaan dari Kejahatan korporasi (corporate crimes) yang harus dicegah dan ditanggulangi, sebab merupakan pelanggaran hak dasar (basic rights, human rights) yang merupakan hak fundamental (hak supra positif, hal elementer, nonderogable rights) 
pekerja/buruh di tempat kerja, juga telah membawa penderitaan, dan kerugian ekonomi yang cukup besar bagi pekerja/buruh (dan keluarganya). Atas berbagai peristiwa kecelakaan banyak pekerja/buruh yang menjadi korban, baik cacat fisik/mental, sakit berkepanjangan, hingga tidak sedikit yang nyawanya melayang di tempat kerja.

Pengusaha/korporasi sebagai pihak yang jauh lebih kuat kedudukannya dari pekerja/buruh baik dari segi-segi moral masyarakat maupun dari segi hukum harus "bertanggung jawab" menempatkan perlindungan K3 pekerja/buruh di atas segala tujuan korporasi mendapatkan keuntungan dan kenikmatan dari hasil usahanya.

Pelindungan K3 pekerja/buruh ini pada dasarnya bukanlah sebuah tuntutan pekerja/buruh yang bekerja di bawah pihak yang kuat, melainkan kewajiban pihak yang kuat (korporasi) yang mempekerjakan pihak yang lemah itu. Inilah sebenarnya konsep perlindungan hubungan kerja antara pengusaha/majikan/korporasi dan pekerja/buruh.

Lebih lanjut, perlindungan K3 pekerja/buruh juga tidak berhenti hanya dalam sebuah kebutuhan dasar (basic need) dan hak dasar (basic right). Akan tetapi, harus menuntut adanya pembebanan "pertanggungjawaban pidana" (criminal responsibility) yang adil kepada "korporasi". Dampak pengabaian terhadap perlindungan K3 pekerja/buruh memerlukan pembebanan pertanggungjawaban pidana korporasi.

\section{Kebijakan Politik Hukum Kriminal}

Berbicara Politik hukum pidana atau kebijakan hukum pidana (penal policy) pada hakikatnya berbicara mengenai pembaharuan hukum pidana (penal reform). Dengan demikian, UU K3 adalah produk arah politik hukum perburuhan nasional masa pembentukannya. Artinya, UU K3 sebagai hukum nasional pertama dibidang K3 adalah hasil pembaharuan dari hukum K3 pada masa Hindia Belanda, yaitu peraturan keamanan (Veiligheids Reglement-VR) 1910 (Stbl. 1910 Nomor 406) karena dianggap tidak sesuai lagi dengan nilai- nilai Pancasila yang menjadi pandangan hidup dalam penyelenggaran negara dan dalam setiap pergaulam masyarakat.
Politik hukum atau kebijakan kriminal oleh pembuat undang-undang saat pembentukan UU K3 memilih menggunakan jalur penal (penal policy) sebagai upaya rasional menanggulangi tindak pidana perlindungan K3 pekerja/buruh. Penanggulangan menitikberatkan kepada sifat repressive (penindakan) sesudah kejahatan terjadi yang dilakukan melalui sistem peradilan pidana. Artinya, sanksi pidana digunakan sebagai pilihan untuk menanggulangi tindak pidana perlindungan K3 pekerja/buruh di tempat kerja.

Hal ini terlihat jelas dari kebijakan formulasi kebijakan hukum pidana UUKK. Oleh karena itu, seyogyanya UU K3 yang dikenal sebagai payung hukum (act umbrella) mampu melakukan fungsinya dalam penegakan hukum pidana.

Namun, sebagaimana penjelasan sebelumnya selama pemberlakuan UU K3 ini, sepanjang tahun begitu banyaknya terjadi kasus-kasus kecelakaan industri di Indonesia tetapi hasil penelitian ini menunjukkan sangat sulit menemukan kasus kecelakaan yang sampai ke tingkat pengadilan. Menurut (Dirdjosisworo, 1994) mengatakan, upaya penanggulangan sangat mempengaruhi aspek ekonomi baik terhadap publik maupun privat dan pada gilirannya akan menentukan keberhasilan pembangunan Indonesia, termasuk pembangunan ketenagakerjaan yang terintegrasi pembangunan nasional

Tingginya kasus-kasus kecelakaan dan korban yang ditimbulkannya memberi gambaran, bahwa perlindungan K3 pekerja/buruh di tempat kerja belum mendapat perhatian serius dan sering diabaikan oleh korporasi. Contoh perkara kasus-kasus kecelakaan yang dikemukakan tidak satupun korporasi yang dipertanggungjawaban secara pidana atas tindak pidana yang dilakukannya. Bahkan ironisnya, tidak satupun dari perkara kasuskasus kecelakaan tersebut yang menggunakan UU K3 sebagai dasar penuntutan dan penjatuhan pidana. Padahal UU K3 yang selama ini dibanggakan dan terus dipertahankan hingga saat menjadi payung hukum terhadap masalah-masalah K3 di Indonesia, ternyata tidak dapat diandalkan dalam upaya menanggulangi tindak pidana 
perlindungan K3 pekerja/buruh. Dengan demikian dapat dikatakan, UU K3 dalam status "disfungsional" dan "non enforceable". Hal ini tentu bertolak dengan semangat pembentukan UUKK yang dijiwai dan diderivasi oleh nilainilai Pancasila yang menjadi pedoman dalam kehidupan berbangsa dan bernegara, termasuk dalam praktek bergaulan masyarakat industri. Terlebih, kedudukan pekerja/buruh dalam hubungan kerja berada dalam posisi yang sangat lemah dibandingkan pengusaha/korporasi, baik dilihat dari segi ekonomi, sosial, maupun psikologis.

Pengawasan ketenagakerjaan memberi peringatan dan dorongan kepada korporasi agar dalam menjalankan usahanya "zero accident", tetapi lebih bersifat moral daripada hukum. Sebaliknya, korporasi yang mengabaikan atau tidak memperdulikan atau melakukan tindak pidana perlindungan K3 pekerja/buruh yang menyebabkan terjadinya kecelakaan hampir dapat dikatakan "zero responsibility". Para korporasi dapat bebas menikmati keuntungan yang diperolehnya tanpa harus dibebani pertanggungjawaban atas tindak pidana perlindungan $\mathrm{K} 3$ pekerja/buruh.

Ketidak berfungsian UU K3 dalam penanggulangan tindak pidana perlindungan K3 pekerja/buruh harus dilihat sebagai perintah atau keharusan untuk mengembalikan UU K3 kepada politik hukum pidana atau kebijakan hukum pidana (penal policy) untuk dilakukan pembaharuan sesuai kondisi dan tuntutan masyarakat agar dapat digunakan dalam upaya penanggulangan tindak pidana Perlindungan K3 pekerja/buruh di tempat kerja. Dengan kata lain perlu dilakukan fungsionalisasi hukum terhadap UU K3.

UU K3 dengan politik hukum pidananya harus masuk kepada sebuah fase, yaitu membuat dan merumuskan kembali sarana penal yang baik. Tugas ini merupakan bidang garapan dari politik hukum pidana atau kebijakan hukum pidana (penal policy). Kebijakan untuk membuat peraturanperaturan hukum pidana (UU K3) yang baik pada hakikatnya tidak dapat dilepaskan dari tujuan penanggulangan tindak pidana terhadap perlindungan K3 pekerja/buruh yang menjadi objek kajian politik kriminal atau kebijakan kriminal (criminal policy). Politik hukum pidana atau kebijakan hukum pidana (penal policy) merupakan bagian dari politik kriminal (criminal policy). Oleh karenanya, jika dilihat dari sudut politik kriminal (criminal policy), politik hukum pidana atau kebijakan hukum pidana (penal policy) identik dengan pengertian "kebijakan penanggulangan kejahatan dengan menggunakan hukum pidana yang baik".

Sehubungan dengan disfungsinya UU K3, mungkin perlu kembali melihat kebelakang bagaimana pembentukan UU K3. Sejarah pembuatan UU K3 tidak terlepas dari nuansa dan suasana politik bangsa Indonesia yang sedang giat melakukan pembangunan untuk mendukung pembangunan pasca kemerdekaan, dan suasana masih terjadinya pergolakan politik sampai tahun 1966, hal ini tentu bisa direnungkan.

Pembentukan UU K3 ini sepertinya dibuat sangat terburu-buru dan terlalu mendesak, terutama terhadap pokok-pokok kebijakan formulasi hukum pidana (UU K3).

Kebijakan hukum pidana (penal policy) adalah bagian kebijakan kriminal (criminal policy) bertujuan untuk membuat hukum pidana itu "dapat berfungsi", beroperasi, bekerja dan dalam wujud nyata. (Nawawi, 1992) menyebut fungsionalisasi hukum pidana ini dengan operasionalisasi hukum pidana atau konkretisasi hukum pidana, yang pada hakikatnya pengertiannya sama dengan "penegakan hukum pidana" dalam upaya untuk menanggulangi tindak pidana perlindungan K3 pekerja/buruh. Fungsionalisasi hukum pidana yang dapat diwujudkan dengan tiga tahap, yaitu tahap formulasi, tahap aplikasi dan tahap eksekusi.

\section{Reformulasi Sistem}

Tahap formulasi hukum merupakan tahap perumusan kebijakan yang menjadi kompetensi pembentuk Undang-Undang. Barda Nawawi Arief berpendapat, bahwa tahap formulasi merupakan tahap yang paling penting dan memegang peranan besar dan startegis dalam operasional kebijakan hukum pidana, khususnya dalam hal pencegahan dan penanggulangan tindak pidana. Kebijakan kriminal harus melihat dan mempertimbangkan berbagai aspek penting terhadap tujuan, sifat bahaya dari perbuatan, keuntungan dan kerugian serta fungsionalisasi dari kebijakan tersebut. Kristian, dengan pendapat yang sama mengatakan, tahap formulasi akan menentukan produk hukum 
yang telah dibuat dapat ditegakkan (enforceable).

Kesalahan/kelemahan

kebijakan

legislatif merupakan kesalahan strategis yang dapat menjadi penghambat upaya pencegahan dan penanggulangan kejahatan pada tahap aplikasi dan eksekusi. Kesalahan/kelemahan kebijakan legislative dalam UUK3 menjadi penghambat di tingkat aplikasi atau penerapan hukum.

Di tahap formulasi, permasalahan UU K3 sehingga tidak dapat berfungsi dan tidak dapat ditegakkan dalam upaya penanggulangan tindak pidana perlindungan K3 pekerja/buruh ialah terletak pada bagian pokok-pokok kebijakan formulasi hukum pidana, yaitu:

1. Perumusan tindak pidana (criminal act);

2. Perumusan pertanggungjawaban pidana (criminal responsibility atau criminal liability); dan

3. Perumusan sanksi (sanction) baik yang berupa pidana maupun tindakan tata tertib,

Hasil penelitian ini menunjukkan penguatan kebijakan formulasi sistem pertanggungjawaban pidana korporasi dalm perlindungan K3 pekerja/buruh Artinya, yaitu penguatan hukum perlindungan K3 pekerja/buruh dalam UU K3 melalui konstruksi pertanggungjawaban pidana korporasi di Indonesia. Muladi mengatakan, dalam pembenaran atau justifikasi korporasi sebagai membuat tindak pidana dan dapat dibebankan pertanggungjawaban secara pidana atas dasar falsafah intergralistik, dimana segala sesuatu yang diukur atas dasar keseimbangan keselarasan antara kepentingan individu dan kepentingan sosial, dasar kekeluargaan.

Akan tetapi pada bagian lain (Dwidja, 1981) mengidentifikasi empat indikator penting dalam memformulasikan sistem pertanggungjawaban pidan korporasi dalm sistem hukum nasional. Indikator tersebut berkaitan dengan :a) perumusan istilah, b) pihak yang dapat dimintakan pertanggungjawaban pidana, c) kualifikasi perbuatan yang dapat dianggap sebagai tindak pidana korporasi; dan d) bentuk pertanggungjawaban atau jenis sanksi pidana yang diancamkan bagi suatu korporasi yang melakukan tindak pidana. Dengan demikian dalam pembaharuan kebijakan pertanggungjawaban pidana korporasi dalam UU K3, maka keempat faktor inilah yang menjadi perhatian utama sehingga UU K3 dapat berfungsi dan dan dapat ditegakkan dalam upaya penanggulangan tindak pidana terhadap perlindungan K3 pekerja/buruh.

Artinya, keberhasilan kebijakan formulasi sistem pertanggungjawaban pidana korporasi UU K3 sangat tergantung kepada perumusan tindak pidana (criminal act) yang terdiri atas unsur subjek hukum korporasi dan perumusan peraturan dan aturan administrasi yang diancam hukum pidana, dan perumusan sanksi (sanction). Oleh karena itu, ketiga bagian pokok-pokok kebijakan formulasi hukum pidana saling berkaitan, sehingga mendapat porsi penjelasan yang seimbang.

Pentingnya keterkaitan tersebut di atas dalam memformulasikan sistem pertanggungjawaban pidana korporasi, sudah menunjukkan penekan hal tersebut. Dikatakan, bahwa formulasi sistem pertanggungjawaban pidana korporasi dalam sejumlah Undang-Undang khusus di luar KUHP inkonsisten, tidak harmonis, tumpang tindih, tidak sinkron atau tidak integral antara ketentuan yang satu dengan ketentuan lainnya.

Hal ini antara lain dapat dilihat, antara lain: sejumlah Undang-Undang khusus di luar KUHP yang merumuskan "korporasi" dengan beragam istilah, termasuk istilah-istilah baru yang belum lazim digunakan. Sehingga menimbulkan pengertian yang ambigu sehingga memerlukan penafsisran (interpretation); terdapat undang-undang yang tidak mengatur sistem pertanggungjawaban pidana; terdapat Undang-Undang yang mengatur sistem pertanggungjawaban pidana korporasi (corporate criminal responsibility). Namun demikian tidak dapat merumuskan sanksi pidana yang dapat dijatuhkan kepada korporasi yang melakukan tidak pidana karena terdapat Undang-Undang yang mengatur sistem pertanggungjawaban pidana korporasi. Akan tetapi sanksi pidana yang diancamkan merupakan sanksi pidana yang hanya ditunjukan kepada manusia alamiah karena terdapat Undang-Undang yang mengatur sistem pertanggungjawaban pidana korporasi. 
Pemikiran dari Barda Nawawi Arief selanjutnya dapat dikembangkan, bahwa pembaruan hukum pidana (penal reform), dalam hal ini pembaharuan UU K3 yaitu pada formulasi (rumusan) sistem pertanggungjawaban pidana korporasi diartikan sebagai suatu upaya atau proses untuk melakukan reorientasi dan reformasi hukum pidana sesuai dengan nilai-nilai sentral sosiopolitik, sosiofilosofik, dan sosio kultural masyarakat Indonesia yang melandasi kebijakan sosial (social policy), kebijakan kriminal (criminal policy), dan kebijakan penegakan hukum (law enforcement policy) di Indonesia.

Dengan kata lain menurut Barda, pembaruan hukum pidana (penal policy) pada hakikatnya harus ditempuh dengan pendekatan yang berorientasi pada nilai (value oriented). Pembaruan hukum pidana tidak dapat dilepaskan dari politik hukum pidana sebagai bagian dari politik hukum yang mengandung arti bagaimana mengusahakan atau membuat dan merumuskan perundangundangan pidana yang baik.

Seyogiyanya juga hukum pidana merupakan bagian integral dari politik kriminal (dalam arti penal) sebagai upaya penanggulangan kejahatan (melalui sarana penal), maka pembaruan hukum pidana juga merupakan bagian intergral dari upaya perlindungan sosial (social defence).

\section{SIMPULAN}

Kebijakan formulasi sistem pertanggungjawaban kejahatan korporasi yang ideal dalam perlindungan K3 adalah dengan merujuk kepada Pancasila. negara hukum Pancasila harus menjunjung tinggi sistem hukum yang menjamin kepastian hukum untuk melindungi pekerja/buruh dari setiap perilaku kejahatan korporasi.

Upaya tersebut dilakukan dengan merumuskan secara eksplisit hukum korporasi yang dapat dibebani pertanggungjawaban, merumuskan kualifikasi perbuatan (regulatory offences) yang dapat dianggap sebagai tindak kejahatan korporasi, sesuai dengan undang-undang administrasi serta merumuskan perbuatan yang dilarang (regulatory offences) dengan memperhatikan perkembangan sanksi terhadap korporasi.

\section{DAFTAR PUSTAKA}

Dirdjosisworo, S. ( 1994). Kejahatan Bisnis (Orientasi dan Konsepsi). Bandung: Mandar Maju.

Dwidja, M. d. ( 1981). Pertanggungjawaban Korporasi dalam Hukum Pidana. Bandung: Sekolah Tinggi Hukum Bandung.

Fidèle Ndjoulou, L. D. (2015). Employer Responsibility for Occupational Health and Safety: Challenges, Issues and Approaches . Journal of Management Policies and Practices Journal of Management Policies and Practices ,1-8.

Hassan, K. H. ( 2014). Undang-undang keselamatan industri di Malaysia. Edisi Kedua. Kuala Lumpur: Dewan Bahasa dan Pustaka.

Mouton. (2006). La sécurité en entreprise : sensibilisation des personnels mise en œuvre d'un plan d'action (2nd Ed.)r. Paris: Dunod.

Munar. (2010). Mainstreaming OSH into Business Management. Luxembourg: Office for Official Publications of the European Communities.

Nawawi, A. B. (1992). Kapita Selekta Hukum Pidana. Bandung: Alumni.

Yaqin. (2007). Legal research and Writing. Malaysia: Petaling Jay. 